\title{
No. XIII.-STOMATOPODA FROM THE WESTERN INDIAN OCEAN.
}

\author{
By L. A. Borradaile, M.A., Lecturer in Natural Sciences at \\ Selwyn College, Cambridge. \\ (Communicated by J. Stanley Gardinek, M.A., F.L.S.)
}

(Plate 22.)

Read 20th June, 1907.

THe two collections on which this paper is based were made respectively by Mr. Stanley Gardiner's expedition in 1905 at various localities between the Maldives and Madagascar, and by Mr. C. Crossland in 1902 in Zanzibar and British East Africa. Together they comprise 15 species of adult forms, belonging to 5 genera, and 11 species of larva, belonging to 6 genera. Two species of adult forms and as many larvæ are new. All the remaining species have already been recorded from various parts of the Indo-Pacific region.

The extensive material, together with the collection in the Cambridge Museum of Zoology, has enabled several specific and varietal questions of difficulty to be solved, and some of the larvæ contribute to the completion of the life-histories of their species.

The following is a list of the adult forms in the collection :-

$$
\text { Genus PROTOSQUILLA, Brooks, } 1886 .
$$

1. Protosquilla pulchella (Miers), 1880.

Gonodactylus trispinosus var. pulchellus, Miers, Ann. Mag. Nat. Hist. (5) v. p. 122 (1880).

Protosquilla trispinosa var. pulchella, de Man, Abb. Senck. Ges. xxv. iii. p. 920.

This species has the following constant differences from $P$. trispinosa :-

i. The middle of the fifth abdominal tergite is smooth, not ridged.

ii. The flat part of the telson, around the three mounds, is both longer and wider than in $P$. trispinosa.

iii. This field around the mounds is not grooved but pitted.

Specimens from Zanzibar and Wasin, British East Africa.

2. Protosquilla tuberculata, sp. nov. (Plate 22. fig. 1.)

Diagnosis.-A Protosquilla with the angles of the rostrum sharp but hardly forming spines, its middle spine almost reaching the cornea of the eyes; the free thoracic and first five abdominal terga smooth, without spines at their angles; the sixth abdominal segment bearing four low mounds, on each of which are three or four sharp knobs, as well as a ridge on each edge ending in a spine; and the telson with four teeth at its hinder end, of which the middle two are rather larger than the outer and all are edged 
with minute spines, at each side a keel bearing a row of blunt teeth, and above four low mounds, two in the middle line and two at the sides, each bearing a few sharp knobs. . Length $18 \mathrm{~mm}$.

One male specimen dredged at Providence, D 1, 39 fathoms.

Genus GONODACTYLUS, Latr., 1825.

'The taxonomy of this genus is at present in some confusion. In the following keys I have endeavoured to arrange the species and varieties in order.

Key to the Species of Gonodactylus.

I. First joint of exopodite of uropod has the teeth of the outer edge curved forwards, and bears a long second joint at some distance from the end. Angles of rostrum form sharp teeth. [Telson bears a large middle swelling, with on each side a smaller ridge and outside this again a still slighter ridge, and has the intermediate teeth of the edge well developed.]

1. Endopodite of uropod curved outwards. Telson smooth, but 3 knobs at end of middle swelling. Outer teeth of telson-edge wanting . G. fimbriatus, Lenz, 1905.

2. Endopodite of uropod curved inwards. Telson bears numerous stout thorns. Outer teeth of telson-edge well developed . . . . . . . G. drepanophorus, de Man, 1902.

3. Related here, but with most of the uropod-teeth straight, is . G. herdmani, Tattersall, 1906.

11. First joint of exopodite of uropod has the teeth of the outer edge curved backwards or nearly straight, and bears a short, broad second joint near the end. Angles of rostrum do not form sharp teeth, except in G. acutirostris.

1. Three long keels on the telson (not including those of the edges), with or without a short keel on each side of the hinder end of the middle keel.

i. Intermediate teeth of the telson-edge well developed.

(1) Angles of the rostrum form sharp teeth. Keels of submedian teeth of telson-edge converge forwards. The small knob usually found in the genus on each side of the telson near its fore edge is wanting.

G. acutirostris, de Man, 1898.

(2) Angles of the rostrum blunt. Keels of submedian teeth of telsonedge do not converge forwards. The above-mentioned knob is in most cases well developed. and at least faintly indicated.

(i) No ridge on the inner side of the keel of the intermediate tooth of the telson-edge. Indo-Pacific.

a. Telson and endopodite of uropods bear long spines . G. acanthurus, Tattersall, 1906.

$b$. Telson smooth, though there may be spines at the end of the

keels. No spines on endopodite of uropods . . . G. chiragra (Fabr.), 1793.

c. Telson bears scattered thorns. Uropods as G.chiragra. G. demani, Hend., 1894.

(ii) A ridge on the inner side of the keel of the intermediate tooth of the telson-edge. W. Atlantic.

a. Telson smooth . . . . . . . . . . . . G. erstedi, Hansen, 1895.

b. Telson roughened with small thorns . . . . . . G. festa, Nobili, 1902.

ii. Intermediate teeth of the telson-edge obsolete.

(1) Telson smooth . . . . . . . . . . . . . . G. espinosus, Borr., 1898.

(2) Telson roughened with small thorns . . . . . G. spinosus, Bigelow, 1893. 
2. Five long keels on the telson (not including those of the edges).

i. Sutures at the sides of the abdominal segments . . . . G. graphurus, Miers, 1875 .

ii. No sutures at the sides of the abdominal segments . . . . G. glaber, Brooks, 1886.

Key to the Varieties of $\mathrm{G}$. chiragra.

I. At the hinder end of the middle keel a smaller ridge is present on each side.

1. The ridges are almost or quite independent of the middle keel, and run forwards parallel with it for some distance. Each of them usually ends in a spine behind.-Var. H. affinis, de Man, 1902 (= segregatus, Lanchester, 1903).

2. The ridges are connected at their hinder ends with the middle keel so as to form an anchor-shaped structure. They are usually short and divergent. They do not bear spines.

i. Keels of sixth abdominal segment and telson compressed. Keels of sixth abdominal segment produced without constriction into long spines. Middle keel of telson ends in a spine. Var. D. smithi, Pocock, 1893.

ii. Keels of sixth abdominal segment and telson rounded, not produced without constriction into spines. Middle keel of telson rarely carries a spine.-Var. A. incipiens, Lanchester, 1903 (type).

1I. The small ridges above mentioned are wanting.

1. The outer teeth of the telson-edge are present.

i. The middle keel of the telson is much broader than the others and has one knob or spine or none at the hinder end.-Var. B. anaucyrus, Borr., 1900.

ii. The middle keel of the telson is much broader than the others and has three spines at the hinder end.-Var. K. confinis, de Man, 1902.

2. The outer teeth of the telson are wanting or very faintly indicated.

i. Keels of telson narrow, with steep sides.-Var. G. acutus, Lanchester, 1903.

ii. Keels of telson very broad, swollen, and rounded.-Var. F. tumidus, Lanchester, 1903.

Key to the Varieties of G. glaber [sphalm. glabrous].

I. Keels narrow or of moderate width, not touching one another. Spines always present at the ends of the three middle keels of the telson, and generally overhang the bases of the keels. (When the spines are short and blunt they are often broken.)-Var. A. ternatensis, de Man, 1902 (=ternatensis, de Man, +glaber, type, de Man,=mutatus, Lanchester, + glaber (pars), Lanchester).

II. Keels broad and swollen so as to touch one another. The spines of the three middle keels of the telson are obsolete and often no trace of them remains.-Var. rotundus, nov. (=glaber (pars), Lanchester).

3. Gonodactylus fimbriatus, Lenz, 1905.

Lenz, Abh. Senck. Ges. xxvii. p. 388, pl. 47. fig. 11.

Specimens from Coetivy, Seychelles.

\section{Gonodactylus chiragra (Fabr.), 1793.}

Squilla chiragra, Fabricius, Ent. Syst. iii. i. p. 513 (1793).

Gonodactylus chiragra, Latreille, Encycl. Méth. x. p. 473 (1825) ; Miers, Ann. Mag. Nat. Hist. (5) v. p. 118 (1880); de Man, Zool. Jahrb. x. Syst. p. 694, pl. 38. fig. 77 (1898); Abh. Senck. Ges. xxv. iii. p. 912 , pl. 27. fig. 66 ; Borradaile, P. Z. S. 1898, p. 34, pl. 5. fig. $4 \&$ pl. 6. fig. 8; Willey's Zool. Results, iv. p. 400 (1900); Lanchester, Gardiner's 'Fauna of the Maldives,' i. p. 444, pl. 23 (1903), in part.

Gonodactylus smithii, Pocock, Ann. Mag. Nat. Hist. (6) xi. p. 475, pl. 20 в. fig. 1 (1893). 
The collection contains specimens of the type variety from various localities in the Seychelles, Amirante, Saya de Malna, Peros, and Zanzibar; of var. affinis from the Seychelles, Amirante, Saya de Malha, and Wasin, British East Africa; of var. acutus from Salomon and Peros ; and of var. smithi from Salomon, Peros, and Zanzibar. The first-mentioned varieties were taken at various depths from the surface to 30 fathoms.

5. Gonodactylus glaber, Brooks, 1886 [sphalm. glabrous]. (Plate 22. fig. 2.)

Brooks, 'Challenger' Report, Stomatopoda, p. 62, pl. 14. fig. 5 \& pl. 15. figs. 7, 9.

Specimens of var. ternatensis, taken at various depths from the surface to 30 fathoms, from Praslin and Coetivy, Seychelles, Cargados Carajos, Zanzibar, and Wasin, British East Africa; and of var. rotundus (Plate 22. fig. 2) from Coetivy, Seychelles, and Zanzibar.

6. Gonodactylus demani, Hend., 1894.

Henderson, Trans. Linn. Soc. (ser.2), Zool. v. p. 4555, pl. 40. figs. 23, 24 (189 ł) ; Nobili, Boll. Mus. Torino, xx. n. 506, p. 11 (1905).

A specimen from Zanzibar.

7. Gonodactylus spinosus, Bigelow, 1893.

Bigelow, Johns Hopkins Univ. Circ. 106, p. 101 (1893) ; Pros. U.S. Nat. Mus. xvii. p. 493 (1894).

A specimen from Praslin, Seychelles.

Genus ODONTODACTYLUS, Bigelow, 1894.

8. Odontodactylus japonicus (de Haan), 1849.

Gonodactylus japonicus, Miers, Ann. Mag. Nat. Hist. (5) v. p. 116 (1880).

The spines at the angles of the fourth and fifth abdominal segments are wanting in the single specimen, which was dredged in 55 fathoms at C 15, Saya de Malha.

9. Odontodactylus brevirostris (Miers), 1884.

Gonodactylus brevirostris, Miers, 'Alert' Report, p. 567, pl. 52. fig. C (1884).

One specimen dredged in 34 fathoms, F 8, Seychelles.

10. Odontodactylus latirostris, sp. nov. (Plate 22. fig 3, 3 a.)

Diagnosis.-An Odontodactylus with the rostrum broad, truncate-triangular; the pleura of the first free thoracic segment not projecting, those of the second truncate, those of the third rounded; the claw of the raptorial limb not much dilated at base, bearing seven teeth on the inner side; teeth at the hinder angles of the fifth and sixth abdominal segments only; the telson with three keels on each side of the middle keel as well as a ridge on the edge, three teeth on the edge on each side, one small tooth inside the outer great tooth, two inside the intermediate, many between the submedians; and the uropods bearing on the basal process two simple teeth, of which the outer is the 
larger and nearly reaches the end of the endopodite, but falls far short of the end of the exopodite.

Length of the largest specimen $55 \mathrm{~mm}$.

Two specimens dredged, E 11, Amirante Group, 25 to 80 fathoms.

Genus PSEUDOSQUILLA, Dana, 1852.

11. Pseudosquilla ciliata (Fabr.), 1793.

Squilla ciliata, Fabricius, Ent. Syst. iii. i. p. 512 (1793).

Pseudosquilla ciliata, Miers, Ann. Mag. Nat. Hist. (5) v. p. 108 (1880) ; Brooks, 'Challenger' Report, Stomatopoda, p. 53, pl. 15. fig. 10 (1886) ; Borradaile, Willey's Zool. Results, iv. p. $402(1900)$.

This species may be distinguished from the nearly related Indo-Pacific species ornata, oculata, and oxyrhyncha by the following characters:-

i. There are no eye-spots.

ii. The rostrum is larger than in the other species, but has no spine.

iii. The eyes are cylindrical.

iv. The third free thoracic segment is not so sharply truncated at the sides as in the other species.

v. The last joint of the exopodite of the uropod equals or outreaches the last spine of the outer edge (except in some small individuals), and outreaches the inner basal spine.

From the Atlantic form (occidentalis, Borr., 1900) described by Brooks (loc. cil.), it differs in having no spine at the hinder angle of the fourth abdominal segment, and the inner basal spine of the uropod longer than the outer.

It is not clear whether the true $P$. ciliata is found in the Atlantic.

Specimens taken at various depths down to 34 fathoms in the Seychelles, Diego Garcia, Zanzibar, and Wasin, British East Africa.

\section{Pseudosquilla ornata, Miers, 1880.}

Miers, Ann. Mag. Nat. Hist. (5) v. p. 111, pl. 3. figs. 5, 6 (1880).

This species differs from its near congeners as follows :-

i. Eye-spots are usually present and defined by a white ring, but they may be replaced by a single median spot of like nature or wanting altogether.

ii. The rostrum is shorter than in $P$. ciliata, but has no spine.

iii. The eyes are broad and flat.

iv. The third free thoracic segment is square at the sides.

v. The last joint of the exopodite of the uropod is short and outreached by the last spine of the outer edge, but outreaches the inner basal spine.

Specimens from Coetivy, Seychelles, and Salomon, Chagos.

$\boldsymbol{P}$. oxyrhyncha, Borr., 1900, differs from this species in having the eye-spots not defined by a white ring, a spine on the rostrum, and the last joint of the exopodite of the uropod outreached by the inner basal spine. 
13. Pseudosquilla oculata (Brullé), 1836.

Miers, Ann. Mag. Nat. Hist. (5) v. p. 110, pl. 3. tigs. 3, 4.

This species differs from $P$. ornata in having four keels on each side of the middle keel instead of three.

Specimens from Coetivy and Salomon, Chagos.

14. ? Pseudosquilla monodactyla, A. M.-Edw., 1878.

Miers, Ann. Mag. Nat. Hist. (5) v. p. 110, pl. 3. figs. 1, 2 (1880).

The single specimen, which is from Zanzibar, agrees with Miers's description, but (1) the rostrum is shorter and broader than in his figure, and its sides more arched;

(2) besides the spines on the telson-edge mentioned by Miers, there is a small spine just behind the root of each of the outer two large spines on each side.

Genus LYSIOSQUILLA, Dana, 1852.

15. Lysiosquilla maculata (Fabr.), 1793.

Squilla maculata, Fabricius, Ent. Syst. iii. i. p. 511 (1793).

Lysiosquilla maculata, Miers, Ann. Mag. Nat. Hist. (5) v. p. 5, pl. 1. figs. 1, 2 (1880).

One specimen from Peros Banhos, Chagos.

The collection also contains the following larval forms :-

1. Odonterichthus tenuicornis, Jurich, 1904.

Jurich, 'Valdivia' Stomatopoda, p. 396, pl. 28. fig. 4. (1904).

Iocality*. $b b, 0-140$ fathoms.

2. Erichthus (? Odonterichthus) rostratus, n. nom.

Erichthus sp., Claus, Abh. k. Ges. Wiss. Gött. 1871, p. 30, pl. 5. fig. 19.

Locality. dd, surface.

3. Preuderichthus communis, Hansen, 1895. (Larva of Pseudosquilla ciliata.)

Hansen, Isopoda, \&c., of the Plankton Exped. p. 86, pl. 8. fig. 5 (1895); Jurich, 'Valdivia' Stomatopoda, p. 395, pl. 29. fig. 1 (1904).

Some specimens which measure about $11 \mathrm{~mm}$. to the end of the rostrum have the small tooth outside the submedian tooth of the telson-edge situated midway between the submedian and the intermediate teeth, not nearer the latter as in later stages. 'The rostrum also is larger, as in the form which I suspect to be the young form of $P$. distinguendus.

Localities. $0,0-180$ fathoms; $e, 50$ fathoms ; $y$, surface; $d d$, surface.

* 'The letters indicating localities refer to Mr. Stanley Gardiner's list of the Plankton collections in an earlier part of this sume series, pp. 169-174. 
4. Pseuderichthus distinguendus, Hansen, 1895. (Larva of Pseudosquillu oculata.)

Hansen, Isopoda, \&c., of the Plankton Exped. p. 86 (1895); Jurich, 'Valdivia' Stomatopodit, p. 394, pl. 38. fig. 5 (1904).

Besides typical specimens, there are some smaller individuals in which the "zoxea spine" in the middle of the hinder edge of the carapace is wanting, and the rostrum is long, far outreaching the antennæ, and bearing underneath five thorns. It seems likely that these are younger stages of Hansen's species. Jurich's specimens measured 27.6 and $30.7 \mathrm{~mm}$. respectively. Mine are not more than $25 \mathrm{~mm}$. long to the tip of the long rostrum.

Locality. C, 0-1200 fathoms.

5. Erichthus (? Pseuderichthus) affinis, n. nom.

Erichthus sp., Claus, Abh. k. Ges. Wiss. Gött. 1871, p. 36, pl. 6. fig. 23.

Locality. $u$, surface.

6. Lysierichthus duvaucelli, Guérin.

Jurich, 'Valdivia' Stomatopoda, p. 393, pl. 26. fig. 7 (1904).

As Jurich says, the "zoxea spine" and lateral spines vary greatly in size.

Locality. C, 0-1200 fathoms; $q, 0-1000$ fathoms; $a a, 0-900$ fathoms.

\section{Alimerichthus multispinus.}

? Erichthus multispinus, Claus, Abh. k. Ges. Wiss. Gött. 1871, pl. 3. fig. 12.

Two specimens of a species of Alimerichthus are closely related to that figured by Claus, but differ in that the foremost of the spines on the lower edge of the carapace is very much larger, and the spines of the hinder angles bear each a small tooth on the inner side at about one-third of their length from the base. Claus's specimen measured $10 \mathrm{~mm}$. in length. The present measure $12 \mathrm{~mm}$., and have the uropods well developed, so that it is probable that they represent a later stage of the same larva.

Locality. O, 0-180 fathoms; $l l, 0-750$ fathoms.

\section{Alima spinigera, sp. nor. (Plate 22. figs. 4, 4a.)}

Diagnosis.-An Alima with the rostrum long, reaching the middle of the antennular flagella, with four spines below ; the carapace of moderate breadth, bearing on its edge four spines, of which the first stands near the fore angle and the rest in the hinder half, the spines of the hinder angles reaching the third abdominal segment and hearing below a small spine, the "zoæa spine," of moderate length, standing just above the hinder edge; the raptorial limbs with three teeth on the claw; the angles of the abdominal segments sharp; the exopodites of the uropods with seven spines; and the telson a little broader than long, the intermediate spines larger than the submedian.

There are two specimens, of which the larger, described above, measures $16.5 \mathrm{~mm}$. to the end of the rostrum. The smaller, $12.5 \mathrm{~mm}$. long, has a narrower carapace, with 
only two spines on its edge, and the first antennal flagella are not longer than the rostrum, which has only two spines below.

Both were taken at Wasin, British East Africa, surface.

9. Alima robusta, Jurich, 1904.

Jurich, 'Valdivia' Stomatopoda, p. 379, pl. 27. fig. 6 (1904).

In a large specimen, $33 \mathrm{~mm}$. long, the teeth at the base of the propodite of the raptorial limb stand further apart than in the smaller ones, which resemble Jurich's figure.

Localities. $l, 0-250$ fathoms ; $n$, surface; $c c$ and $d d$, surface.

10. Alima hyalina, Leach, 1818.

Jurich, ' Valdivia' Stomatopoda, p. 383 (1904).

Alima gracilis, H. M.-Edwards, Hist. Nat. Crust. ii. p. 509 (1837).

Alima angusta, Dana, U.S. Expl. Exped., Crust. i. p. 631, pl. 42. fig. 2 (1852).

A list of references to this common species will be found in Jurich's paper.

Localities. ee, surface; $u$, surface; dredging F 2, Seychelles, 0-31 fathoms.

11. Alima gracillima, sp. nov. (Plate 22. figs. 5-5 b.)

The collection contains two specimens of an Alima closely related to A. hyalina, from which, however, it differs in the narrowness of the carapace and the shortness of the spines at the hinder angles. All the limbs are present in the specimens, which measure respectively 24 and $25 \mathrm{~mm}$. to the end of the rostrum.

Locality. $k, 150$ fathoms.

\section{EXPLANATION OF PLATE 22.}

Fig. 1. Protosquilla tuberculata, sp. nov., $\times 5$.

Fig. 2. Gonodactylus glaber, Brooks, var. rotundus, n.: tail-fin, $\times 3$.

Fig. 3. Odontodactylus latirostris, sp. nov., $\times 1 \frac{3}{4}$.

Fig. $3 a$. " " side of last three thoracic segments, $\times 2$.

Fig. 4. Alima spinigera, sp. nov., $\times 6$.

Fig. 4a. " $"$ side of carapace, $\times 6$.

Fig. 5. Alima gracillima, sp. nov., $\times 4$.

Fig. 5 a. ," $\quad$ side of carapace, $\times 6$.

Fig. $5 b$. ",$\quad$ tail-fin, enlarged. 
PERCY SLATHN TRU ET EXTEDTIUN.

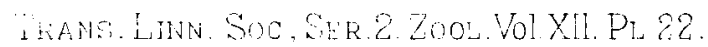

(Botrainalip)

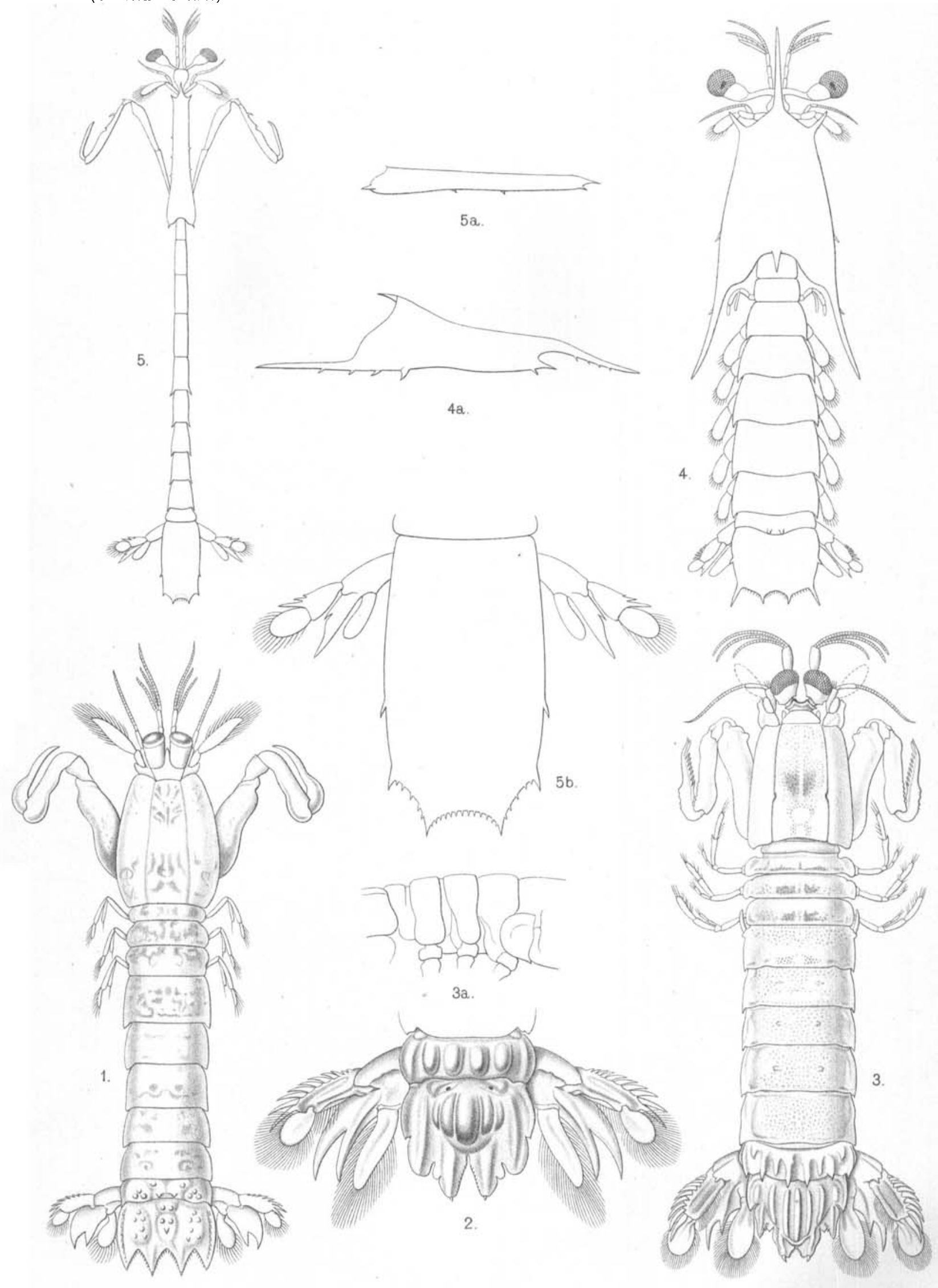

STOMATOPODA FROM THE INOIAN OCEAN. 